\title{
Cross-Border Life in Europe: Daily Mobility in the Trinational Metropolis of Basel*
}

\author{
La vida transfronteriza en Europa: \\ la movilidad diaria en la metrópolis trinacional de Basilea
}

\author{
Yann Dubois ${ }^{1}$ \\ Urban Sociology Laboratory, EPFL, Lausanne, Switzerland \\ yann.dubois@epfl.ch
}

doi: http://dx.doi.org/10.18543/ced-56-2017pp133-160

\begin{abstract}
In Europe about 2 million people work and live in two different countries. While at the European scale cross-border workers only account for a limited portion of the working-age population, in some regions cross-border work takes a huge importance. In these regions, cross-border work generates many impacts on local territories and on their inhabitants in terms of housing, mobility or purchasing power, especially because of the wide salary differentials between some borders regions, like between Switzerland and its neighbouring countries. Indeed, Switzerland is the country in Europe which hosts the largest amount of cross-border workers. Research on border regions focus mainly on the macroscopic aspects of cross-border relationships, such as economic integration or cross-border cooperation, leaving partly aside the effects that cross-border work has on territories or their inhabitants. Thus, this article looks at the link between cross-border work and the other aspects of daily life such as consumption or leisure and more generally living conditions in the trinational metropolis of Basel. For this purpose, we conducted a study with inhabitants of the metropolitan area of Basel, in which cross-border work is largely practised - using a mixed methods design; fifteen interviews were conducted, followed by a quantitative survey (1,615 individuals). Results show that working or not across the border, in Switzerland, has a large

* Recibido el 23 de diciembre de 2016, aceptado el 26 de febrero de 2017.

1 The author thanks D. Christie, G. Drevon, M.-A. Messer, and E. Ravalet for their helpful comments on this manuscript. This research was funded by the Swiss National Science Foundation.
\end{abstract}


impact on living conditions and influences the intensity and/or the destination of cross-border practices (leisure and consumption). Whereas cross-border workers tend to favour Switzerland, this country is "financially less" accessible to the rest of the population. The analysis of the inhabitants' lifestyles also highlights two issues linked to cross-border work that the trinational metropolis of Basel faces and that may cause tension in the local population, i.e. 1) the highly differentiated living conditions between cross-border workers and the rest of the population 2) the large car use of cross-border workers.

Keywords: Cross-border mobility, cross-border work, lifestyles, Basel.

Resumen: En torno a dos millones de personas trabajan en un país distinto del que residen. Aunque a nivel europeo los trabajadores transfronterizos constituyen una parte minoritaria de la población activa, en algunas regiones el trabajo transfronterizo tiene un peso importante. En tales regiones, el trabajo transfronterizo tiene numerosos impactos sobre el territorio y la población en términos de alojamiento, movilidad o poder adquisitivo, debido en especial a las diferencias salariales entre algunas regiones fronterizas, como entre Suiza y sus países vecinos. De hecho, Suiza es el país de Europa con el mayor número de trabajadores transfronterizos. La investigación sobre las regiones transfronterizas se ha concentrado fundamentalmente en los aspectos macroscópicos, como la integración económica o la cooperación transfronteriza, obviando parcialmente los efectos que el trabajo transfronterizo tiene sobre los territorios y sus habitantes. Este artículo se interesa a la relación entre trabajo transfronterizo y otros aspectos de la vida cotidiana, como el consumo o el ocio, y de forma más general a las condiciones de vida de la metrópolis trinacional de Basilea. Para ello, se ha realizado un estudio de los habitantes del área metropolitana de Basilea, en la cual el trabajo transfronterizo está largamente extendido - utilizando une metodología mixta con la realización de 15 entrevistas, seguidas de una encuesta cuantitativa (1615 individuos). Los resultados muestran que trabajar o no al otro lado de la frontera en Suiza tiene un fuerte impacto en las condiciones de vida e influencia la intensidad y/o el destino de las prácticas transfronterizas (ocio y consumo). Mientras que los trabajadores transfronterizos tienden a favorecer Suiza, este país es financieramente menos accesible para el resto de la población. El análisis de los modos de vida de los habitantes también pone de relieve dos problemas ligados al trabajo transfronterizo a los que hace frente la metrópolis trinacional de Basilea y que pueden generar tensiones en la población local, a saber 1) las grandes diferencias en las condiciones de vida entre los trabajadores transfronterizos y el resto de la población 2) el gran uso del vehículo particular por parte de los trabajadores transfronterizos.

Palabras clave: Movilidad transfronteriza, trabajo transfronterizo, estilos de vida, Basilea. 


\section{Introduction}

The Brexit referendum in the United Kingdom in June 2016 and the vote against 'mass immigration' in Switzerland in February 2014 struck a hard blow against the idea of one Europe where mobility across borders would be unimpeded. In the United Kingdom, immigration was one of the key arguments used by Brexit supporters. In Switzerland, the single issue of the vote was the regulation and reduction of flows of individuals through national borders: European and Extra-European immigrants, but also crossborder workers, i.e. non-resident workers who commute daily towards Switzerland, were targeted by this vote.

These two cases mark the return of a certain reluctance towards free movement of people after decades of opening of borders and the development of international co-operation through the European project ${ }^{2}$. In the 1990s, Ohmae along with other authors wrote about a borderless world or even the end of the nation state, linked with the globalization process and the increase of international flows of information, capital, people and goods $^{3}$. Long before Brexit and the Swiss vote on mass immigration, such theories had already been largely put into question. First, at the global scale, there is a tendency towards 're-bordering', i.e. the reinforcement of borders and the creation of new ones ${ }^{4}$. Extending this idea, Balibar, among others, describes (in the context of war against terrorism) the multiplicity of borders spreading far away from their initial boundaries ${ }^{5}$. Finally, at the individual scale, despite the increased permeability of borders and their changing functionality, they continue to play a crucial role in the identity construction process, as well as in daily life, which mostly continues to take place within national borders ${ }^{6}$.

2 Gerald Blake,"State limits in the early twenty-first century: Observations on form and function", Geopolitics 51 (2000): 1-18.

${ }_{3}$ Kenichi Ohmae, The borderless world. Power and strategy in the interlinked economy. (London: Collins, 1990).

${ }^{4}$ Michel Foucher, L'obsession des frontières (Paris: Perrin, 2007). Leslie R. Alm and Ross E. Burkhart,"Bridges and Barriers: The Lake Superior Borderlands", Journal of Borderlands Studies 281 (2013): 47-60.

5 Etienne Balibar, "The Borders of Europe", in Cosmopolitics: Thinking and Feeling Beyond the Nation, Cheah P. and Robbins B. (eds.): (Minneapolis: University of Minnesota Press, 1998), 216-229. Anssi Paasi and Eeva-Kaisa Prokkola,"Territorial Dynamics, Cross-border Work and Everyday Life in the Finnish-Swedish Border Area", Space and Polity 121 (2008): 13-29. Chris Rumford,'Towards a Multiperspectival Study of Borders", Geopolitics 174 (2012): 887-902.

${ }^{6}$ David Newman,'The lines that continue to separate us: borders in our 'borderless' world", Progress in Human Geography 302 (2006): 143-161. 
Thus, only a small percentage of the European population live or/and work in another European country, despite the opportunities offered by open borders and the establishment of the free movement of persons as a central concept of the European Union. However, flows across borders, such as immigration or cross-border work-the form of mobility which this article focuses on-are liable to cause tension at local level in the regions where they are the most developed. By focusing on the lifestyles of the inhabitants of the cross-border metropolitan area of Basel, that is their living conditions and their (cross-border) spatial practices (between Switzerland, France and Germany), this article aims to determine the impact of national borders on their daily life. For this purpose, we compare the spatiality of lifestyles of cross-border workers and non-cross-border workers, and the issues that these spatial practices raise.

After reviewing the literature on cross-border mobility, we contextualize the question of cross-border work in Europe, in Switzerland and in the metropolitan area of Basel (case study). Regarding methodology, this article is based on a mixed methods approach conducted with inhabitants of the three countries involved (Switzerland, Germany and France) in the Basel area; it combines qualitative interviews, a quantitative survey and contextual data. Finally, the results section is divided in three sections: the living conditions of cross-border and non-cross border workers and nonworkers, their spatial practices at the cross-border scale and finally the issues raised by these practices.

\section{Mobility and Borders}

Borders, functioning both as barriers and bridges, help produce differentiated territories, with a particularly rich and diverse offer, unique to each side ${ }^{7}$. Indeed, when they are permeable, borders and the territories they give access to can be considered as resources or opportunities for various economic, political and individual actors ${ }^{8}$. For individuals, a localization close to the border offers them simultaneously a secure "inside" national

7 Liam O'Dowd,'The Changing Significance of European Borders", Regional \& Federal Studies 124 (2002): 13-36. Henk van Houtum, 'The Mask of the Border', in The Ashgate Research Companion to Border Studies, Wastl-Walter D. (ed.): (Farnham: Ashgate, 2011), 49-61.

${ }^{8}$ Marina Van Geenhuizen and Remigio Ratti, Gaining Advantages from Open Borders. An active space approach to regional development (Aldershot: Ashgate, 2001). Christophe Sohn,'The Border as a Resource in the Global Urban Space: A Contribution to the CrossBorder Metropolis Hypothesis", International Journal of Urban and Regional Research 385 (2013): 1697-1711. 
space and a facilitated access to an "outside" international space with its various opportunities (jobs/salaries, differences in the supply of goods and services, etc.). These differences result from price, wage, taxation or legal system differentials between neighbouring countries: the exploitation of these differentials leads to movements through the border and brings economic benefits to the border regions and their inhabitants - at least some of them ${ }^{9}$.

Cross-border work, the main focus of this article, is one of the more classical forms of the exploitation of resources offered by an open border. In brief, it consists in living in one country and working in another. Crossborder work is often motivated by wage differentials between countries, as between Switzerland and the neighbouring countries ${ }^{10}$ : Swiss salaries are around $50-75 \%$ higher than those in the adjacent French departments ${ }^{11}$. Financial attractiveness, combined with a high demand for working force and a softening of rules regulating cross-border work, have contributed to a strong development of this kind of mobility: the number of cross-border workers in Switzerland has doubled during the last 20 years $^{12}$. Luxembourg shows several similarities to the Swiss case regarding the large use of the cross-border workforce and high salary and living cost differentials ${ }^{13}$. Shortage of local (or national) jobs, better working conditions or positions corresponding better to an individual's profile or expectations are other important motivations for cross-border work.

Positive aspects of cross-border work are mostly recognized in political and economic spheres, as well as to a certain extent in the local population: cross-border workers are an essential workforce in the local Swiss economies $^{14}$. However, the feeling that cross-border workers contribute to unemployment and depressed wages, remains strong. Even though many studies in Geneva or in the Swiss-Italian part (Ticino) state that these negative effects do not exist or are not significant. Actually, cross-

9 Doris Wastl-Walter, "Borderlands", in International Encyclopedia of Human Geography, Kitchin R. and N. Thrift (eds.): (Oxford: Elsevier, 2009), 332-339.

10 Véronique Soutif, L'intégration européenne et les travailleurs frontaliers de l'Europe occidentale (Angers, 1997). Rachid Belkacem, et al.,»Les travailleurs frontaliers lorrains», Travail et emploi 105 (2006): 65-77. Claudio Bolzman and Marie Vial, Migrants au quotidien : les frontaliers. Pratiques, représentations et identités collectives (Zurich: Seismo, 2007).

11 Marie-Paule Thomas, et al., Choix résidentiels et modes de vie dans l'agglomération franco-valdo-genevoise (Grand Genève, 2011).

12 Office fédéral de la Statistique, Autorisations frontalières, 2016.

13 Philippe Gerber,"Advancement in Conceptualizing Cross-Border Daily Mobility: the Benelux Context in the European Union", EJTIR 122 (2012): 178-197.

${ }_{14}$ Michele Pellizzari, et al., La contribution des actifs transfrontaliers à l'économie de l'Espace lémanique. Rapport à l'intention du Conseil du Léman (Université de Genève: Laboratoire d'économie appliquée, 2016). Yves Flückiger and Yves Perrin, Pas de lien direct entre chômage et main-d'oeuvre frontalière (Genève, 2005). 
border workers do well on the job market because their profiles are better suited to the needs of the local economy, in terms of education and employability than many unemployed Swiss ${ }^{15}$. Whereas these studies in Geneva and Ticino found almost no negative effects; another conducted in the Swiss-French Jura region is more nuanced. It declares that a substitution effect of the local workforce by cross-border workers exists, as well as a tendency towards depressed wages, especially in economic sectors without collective agreements ${ }^{16}$. Even if the direct effect of cross-border work on unemployment and wages in Switzerland is debated, there is no doubt that the presence of cross-border workers and (European) immigrants, as well as the higher mobility of Swiss people within their national borders have increased the competition in local job markets in Switzerland.

\section{Impacts of Cross-border Work on Territories}

The attractiveness of cross-border work in Switzerland or Luxembourg goes along with strong population movements towards these countries. The regions adjacent to these countries have become very attractive because they allow people to have access to (financially) interesting jobs while continuing to live in the home country with its lower cost of living. It should be noted that on one side Switzerland and Luxembourg are particularly expensive with limited access to affordable housing; on the other side, avoiding moving abroad - while working there - provides multiple advantages in terms of administrative paperwork or moorings ${ }^{17}$.

The growth of cross-border work goes along with a strong tendency towards urban sprawl in formerly rural border areas close to Swiss or Luxembourg employment centres, through the construction of numerous detached or semi-detached houses ${ }^{18}$. This attractiveness leads to an increase

15 Pierre Kempeneers and Yves Flückiger, Immigration, libre circulation des personnes et marché de l'emploi (Genève: Observatoire Universitaire de l'Emploi, 2012). Moreno Baruffini, et al., Approfondimento della situazione del mercato del lavoro ticinese negli anni successivi all'introduzione dell 'Accordo sulla Libera Circolazione delle Persone (ALCP) Rapporto di ricerca (Lugano: IRE-Università della Svizzera italiana, 2015).

16 Olivier Crevoisier and Alexandre Moine, Impact de l'accord bilatéral relatif à la libre circulation des personnes sur la région transfrontalière du canton de Neuchâtel et du département du Doubs (Neuchâtel - Besançon: GRET-THEMA, 2006).

17 Thomas, et al., Choix résidentiels et modes de vie dans l'agglomération franco-valdogenevoise

18 Éric Auburtin,»Anciennes frontières, nouvelles discontinuités: les impacts du développement du travail frontalier sur les populations et les territoires du Nord lorrain», Espace populations sociétés 20052 (2005): 199-210. 
in housing and living costs in the whole area ${ }^{19}$. The high proportion of cross-border workers has impacts on the wage structure, as they have higher pays. These two elements may increase social inequality between cross-border workers and non-cross-border workers, raising strong issues regarding the cohabitation of the inhabitants of these border regions ${ }^{20}$. These residential mobilities are strongly marked by economic motives and are likely to increase social and spatial segregation, given that some territories in cross-border cities become financially inaccessible to many people ${ }^{21}$.

Residential mobility in border regions is not restricted to mobility inside the national borders; we also observe residential mobility across borders. It concerns both people trying to move closer to their jobs, as well as Swiss (around Geneva this phenomenon is widespread) or Luxembourg citizens, escaping from their own expensive, overloaded housing market, to achieve access to property - especially detached houses - in the cheaper, neighbouring country while keeping their job in their 'home' country ${ }^{22}$.

Moreover, mobilities linked to cross-border work result in numerous trips across borders. Combined with the development of urban sprawl and undeveloped cross-border transport infrastructure, especially for public transportation, cross-border mobility is mostly done by car $^{23}$. Indeed, the presence of two or more states makes it more difficult to set up infrastructure projects at the cross-border scale (because of financial, administrative, legal or governance aspects) ${ }^{24}$. Thus, in the Luxembourg metropolitan area, Auburtin ${ }^{25}$ notes that the car is by far the most used transport mode by cross-border workers; the traffic conditions are described

${ }_{19}$ Crevoisier and Moine, Impact de l'accord bilatéral relatif à la libre circulation des personnes sur la région transfrontalière du canton de Neuchâtel et du département du Doubs. Rafael Costa and Thierry Eggerickx,»Diversité démographique et profils migratoires des espaces frontaliers belges», Géo-Regards 4 (2011): 113-134.

${ }^{20}$ Crevoisier and Moine, Impact de l'accord bilatéral relatif à la libre circulation des personnes sur la région transfrontalière du canton de Neuchâtel et du département du Doubs

21 Thomas, et al., Choix résidentiels et modes de vie dans l'agglomération franco-valdogenevoise

22 Anke Strüver,"'Everyone Creates One's Own Borders': The Dutch-German Borderland as Representation", Geopolitics 93 (2004): 627-648. Costa and Eggerickx, "Diversité démographique et profils migratoires des espaces frontaliers belges". Thomas et al., Choix résidentiels et modes de vie dans l'agglomération franco-valdo-genevoise.

23 Piet Rietveld,"Barrier Effects of Borders: Implications for Border-Crossing Infrastructures", EJTIR 122 (2012): 150-166.

${ }^{24}$ Antoine Beyer, «L'enjeu transfrontalier de l'extension des réseaux de tramway urbain à Strasbourg et à Bâle», in Le tramway dans la ville. Le projet urbain négocié à l'aune des déplacements, P. Hamman (ed.): (Rennes: Presses universitaires de Rennes, 2011), 253-267.

25 Auburtin, «Anciennes frontières, nouvelles discontinuités: les impacts du développement du travail frontalier sur les populations et les territoires du Nord lorrain». 
as close to saturation on some highways. The mobility situation is also very complicated in the Geneva ${ }^{26}$ or Ticino ${ }^{27}$ regions, with a high share of car use in cross-border trips. Likewise in the Swiss-French Jura region, access points to Switzerland are very busy and poorly suited to such traffic, with some sections in town centres receiving up to 25,000 cars a day, which causes congestion ${ }^{28}$. In Basel, even though car use is frequent, the metropolis distinguishes itself through remarkable cross-border transport infrastructure: S-Bahn, trams and buses cross the borders ${ }^{29}$.

\section{Context: Cross-border Work in Europe and Switzerland}

At the European scale, around two million people work in another country than the one they live in, representing only $0.6 \%$ of the working-age population. According to van Houtum and van der Velde, most individuals, influenced by their 'national habitus', do not consider the opportunities located on the other side of the border: such a process only becomes possible when the 'threshold of indifference' is passed ${ }^{30}$. Furthermore, obstacles to cross-border mobility (language or mentality differences, lack of information, administrative aspects, etc.) are often considered too high and this also limits such practices ${ }^{31}$.

Nevertheless, this result may be misleading, because in some border regions, the share of cross-border workers can reach up to $40 \%$, or even more in some municipalities. France is the country which hosts the greatest number of people working abroad $(437,900,1 \%$ of the population), followed by Germany, Poland, Slovakia and Italy. Among the five regions (NUTS2) most concerned by cross-border work three are adjacent to Switzerland: Rhône-Alpes, Alsace and Freiburg im Breisgau (see Table 1).

${ }^{26}$ CITEC, Enquête sur les flux de déplacements à la frontière: résultats 2011, Rapport technique, GLCT Transports publics Grand Genève, 2012.

27 Aurelio Vigani,»Transports, frontière et développement territorial de la Regio Insubrica», Géo-Regards 4 (2011): 95-11.

${ }^{28}$ Crevoisier and Moine, Impact de l'accord bilatéral relatif à la libre circulation des personnes sur la région transfrontalière du canton de Neuchâtel et du département du Doubs

$29 \mathrm{PTV}$, Renforcement des transports en commun et de mobilité combinée ( $P \& R, B \& R)$ de l'Eurodistrict Trinational de Bâle. Enquête Cordon aux frontières de l'Eurodistrict Trinational de Bâle (TIM, TC et modes doux), ETB 2012.

${ }^{30}$ Henk van Houtum and Martin van der Velde,'The power of cross-border labour and market immobility", Tijdschrift voor Economische en Sociale Geografi 951 (2004): 100-107.

${ }^{31} \mathrm{MKW}$ and Empirica, Scientific Report on the Mobility of Cross-Border Workers within the EU-27/EEA/EFTA Countries (Munich, Sopron: European Commission DG Employment and Social Affairs, 2009). 


\section{Table 1}

People working abroad and living in the European Union (2015)

\begin{tabular}{lcc|lc}
\hline Country & $\begin{array}{c}\text { Cross-border } \\
\text { workers }\end{array}$ & $\begin{array}{c}\text { \% of cross-border workers in } \\
\text { the working-age population } \\
(15-64 \text { years old })\end{array}$ & Regions (NUTS 2) & $\begin{array}{c}\text { Cross-border } \\
\text { workers }\end{array}$ \\
\hline France & 437,900 & $1.0 \%$ & Rhône-Alpes & 114,000 \\
Germany & 286,100 & $0.5 \%$ & Lorraine & 110,800 \\
Poland & 154,500 & $0,6 \%$ & Nord-Est & 78,400 \\
Slovakia & 147,200 & $3,8 \%$ & Alsace & 67,000 \\
Italy & 121,600 & $0.3 \%$ & Freiburg im Breisgau & 62,300 \\
\hline
\end{tabular}

Source: Employment and commuting by NUTS 2 regions, EUROSTAT 2015.

Indeed, Switzerland attracts the greatest number of cross-border workers in Europe (around 300,000), followed by Luxembourg with 180,000. Germany, the Netherlands and Austria complete the picture of the countries attracting the largest quantity of cross-border workers, with between 90,000

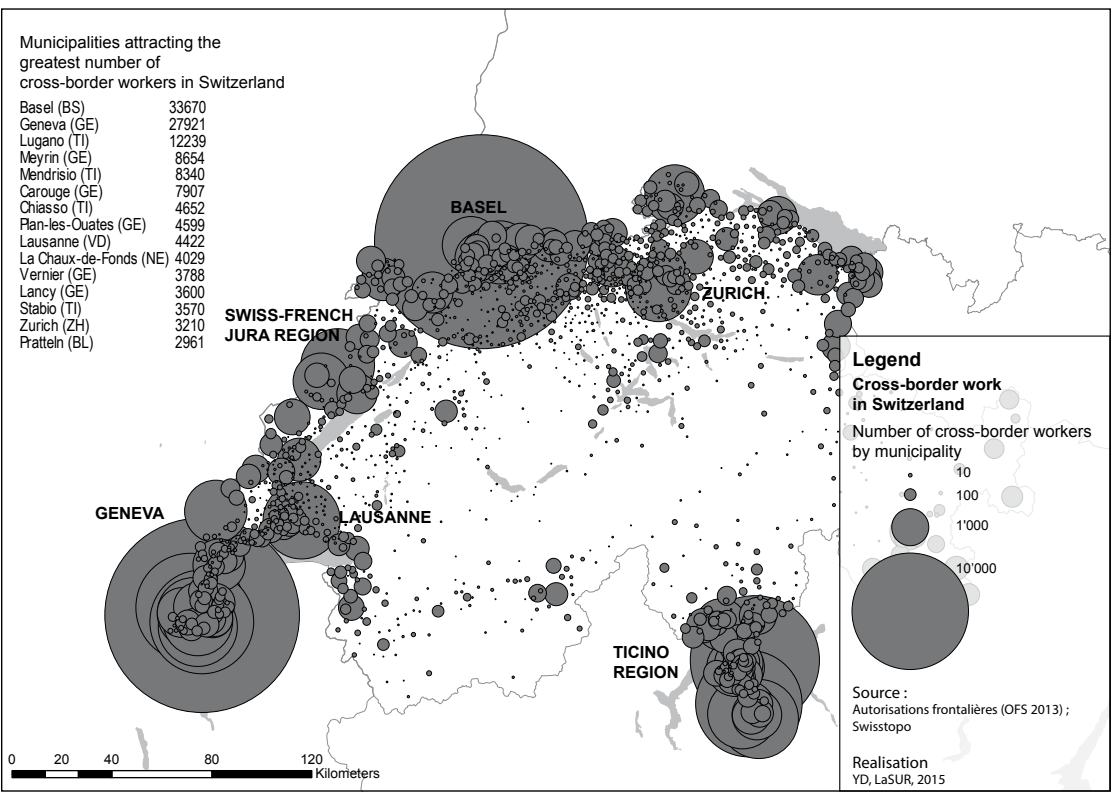

\section{Map 1}

Cross-border work in Swiss municipalities (in absolute numbers), 2013 
and 50,000 each, clearly a lot less than Switzerland and Luxembourg ${ }^{32}$. In the Swiss economy, cross-border work has a huge importance in cities close to borders, as Basel, Geneva or the Ticino region, where the cities of Lugano, Mendrisio or Chiasso attract tens of thousands of cross-border workers. The Swiss-French Jura region, Lausanne, Eastern Switzerland and Zurich are also concerned by this phenomenon. Whereas in Basel or Geneva, cross-border workers occupy about $25 \%$ of all jobs, in smaller towns their share can reach up to 51\% in Meyrin (near Geneva) or 59\% in Mendrisio. The map above shows the Swiss municipalities where crossborder work is quantitatively most important.

The trinational metropolis of Basel, at the intersection of Germany, France and Switzerland, counts 820,000 inhabitants, the greatest part of which live in Switzerland. One of the main features of the metropolitan area is the presence of two national languages (German and French) and

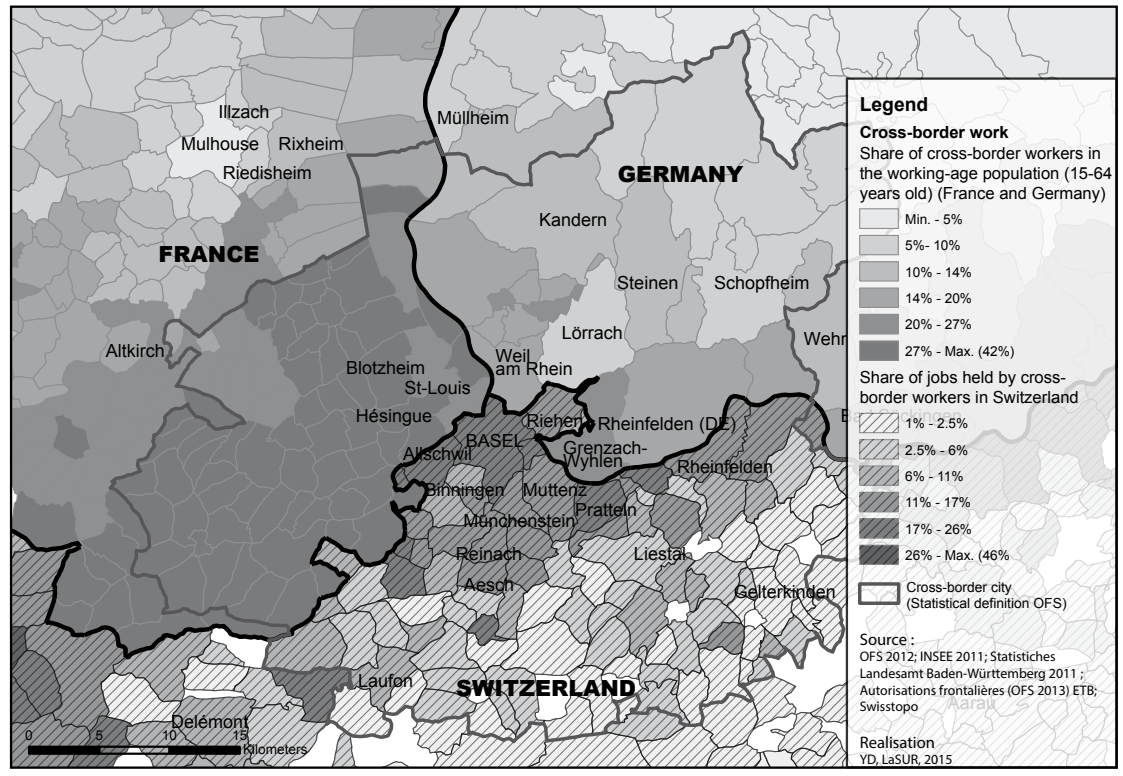

Map 2

Cross-border work in the trinational metropolis of Basel

${ }^{32} \mathrm{MKW}$ and Empirica, Scientific Report on the Mobility of Cross-Border Workers within the EU-27/EEA/EFTA Countries. 
three Germanic dialects. It is also characterized by large cross-border flows and intense cross-border co-operation between the three countries ${ }^{33}$.

The map 2 gives a better insight of the Basel region and of cross-border work. In quantitative terms, the German municipalities of Lörrach, Rheinfelden, Weil am Rhein or Freiburg im Breisgau, and the French municipalities of Saint-Louis, Huningue or the Mulhouse urban region are home to the largest quantity of cross-border workers. In relative terms, cross-border work is highly developed in the French part; between $25 \%$ and $40 \%$ of the workingage population of the municipalities close to the Swiss border are cross-border workers. This implies a strong dependency of the region on the Swiss economy. In the German part, the cross-border worker share is smaller: it accounts for 10 to $20 \%$ of the working-age population. This map also shows that in Switzerland cross-border workers occupy a relatively large part of jobs in the municipalities next to the border, but also in the most urban part of Basel area.

\section{Questions and methods}

Although the introduction and the context showed the importance of cross-border work in some regions, the scientific literature tends to focus on the macroscopic aspects of cross-border relationships, such as economic integration or cross-border co-operation. By combining studies on employment, living conditions, housing or mobility, it nevertheless appears that cross-border work has strong effects on territories and their inhabitants. For these reasons cross-border work has induced animated discussions and even criticism among the population. This tension concerns daily life, namely the pressure on jobs or on living conditions (especially the cost of living in the border regions) or the daily (motorized) flows of cross-border workers passing through villages and cities. These questions have a major importance in the functioning of cross-border cities and in the understanding of the issues at stake regarding the regulation of mobility in Switzerland and in Europe. By focusing on the lifestyles of inhabitants, i.e. their living conditions and spatial practices, this article aims to answer the following question: what are the impacts of the presence of a national border on the daily life of the inhabitants of a cross-border urban area?

To deal with daily life in a cross-border city, namely the issues of work, mobility, leisure or shopping practices, we set up a mixed methods design, combining contextual, qualitative (interviews) and quantitative (survey) data. The temporality of data collection and analysis is organized

33 Christophe Sohn, et al.,"Cross-border metropolitan integration in Europe: the case of Luxembourg, Basel, and Geneva", Environment and Planning C: Government and Policy 27 (2009): 922-939. 
in two stages. The first consists in data collection and a first analysis of the contextual data (1), followed by the interviews (2) and the quantitative survey (3). This enables the different types of data to enrich the collection and analysis of the downstream data. In the second stage, these three types of data undergo an integrated analysis.

The first element, the territorial analysis, aims at precisely describing the trinational metropolis of Basel with a contextual purpose, but also to understand the influence of the territory on individuals and their lifestyles. This requires the collection of data on the population, cross-border work, transport infrastructure, and the supply of goods and services.

The second element is composed of fifteen interviews done in France and Switzerland with people in employment. Whereas these exploratory interviews were at first conceived as a tool to help the survey design, they prove to be useful for other purposes. They contributed to improving the conceptual framework, to specify hypotheses, create new ones and offer a significant analytical contribution.

The third element is a quantitative survey by questionnaire, distributed in four very similar versions (Basel, Swiss, French, and German versions): 1615 individuals living in the three countries answered it (an answer rate of around 20\%). The setting up of such a survey was driven by the lack of available data at the cross-border scale to address questions of daily mobility and lifestyles. In this article, focused on cross-border work and its impacts on daily life, we concentrate our analysis on the lifestyles of the inhabitants (cross-border workers and non-cross-border workers) of the French and the German parts of the metropolitan area.

\section{Results}

\section{What impact does cross-border work have on living conditions?}

Before analysing the living conditions of the inhabitants of the French and German parts of the urban area, it is necessary to specify the survey sample in terms of work and places of work. In Germany, $41.7 \%$ of the sample lives and works in its own country, versus $21.9 \%$ who are cross-border workers and 36.4\% who are not working. In France, 28.2\% of the respondents live and work in France, $39.9 \%$ are cross-border workers and the remaining $31.9 \%$ do not work ${ }^{34}$. Flows are almost entirely

${ }^{34}$ Cross-border workers are overrepresented in our sample (around 10 points too high); unfortunately, because of the lack of available and concordant data, we have preferred not 
directed towards Switzerland (only $1.6 \%$ of the French sample works in Germany), which is why we do not differentiate cross-border workers by the localization of their workplace in the following analyses.

From a quantitative point of view, working in Switzerland rather than in France or Germany allows people to access to higher wages (it must be noted that the income is weighted by the cost of living in each country and the consumption unit of each household). Thus, in Germany, only 10\% of the cross-border workers are in the lowest income category compared to $30 \%$ of non-cross-border workers and $42.7 \%$ of non-workers. On the contrary, $67 \%$ of cross-border workers are to be found in the highest income category versus only around $20 \%$ of the rest of the population. In France, trends are similar: cross-border workers have much larger incomes. It is even more obvious because the average income is lower in France than in Germany. Differences are thus bigger: $65.1 \%$ of non-cross-border workers are in the lowest category and only $16.3 \%$ in the highest, versus respectively $12.1 \%$ and $51.9 \%$ among cross-border workers. Non-workers have a similar income to non-cross-border workers.

\section{Table 2}

Income: Differences between cross-border workers and non-cross-border workers

\begin{tabular}{lccc|ccc}
\hline & \multicolumn{3}{c|}{ German } & \multicolumn{3}{c}{ French } \\
\cline { 2 - 7 } & $\begin{array}{c}\text { Cross-border } \\
\text { workers }\end{array}$ & $\begin{array}{c}\text { Non-cross- } \\
\text { border } \\
\text { workers }\end{array}$ & $\begin{array}{c}\text { Non- } \\
\text { workers }\end{array}$ & $\begin{array}{c}\text { Cross-border } \\
\text { workers }\end{array}$ & $\begin{array}{c}\text { Non-cross- } \\
\text { border } \\
\text { workers }\end{array}$ & $\begin{array}{c}\text { Non- } \\
\text { workers }\end{array}$ \\
\hline Low income & $10.0 \%$ & $29.9 \%$ & $42.7 \%$ & $12.2 \%$ & $65.1 \%$ & $65.5 \%$ \\
Middle income & $22.9 \%$ & $53.0 \%$ & $35.9 \%$ & $35.9 \%$ & $18.6 \%$ & $21.4 \%$ \\
High income & $67.1 \%$ & $17.2 \%$ & $21.4 \%$ & $51.9 \%$ & $16.3 \%$ & $13.1 \%$ \\
\hline & $100.0 \%$ & $100.0 \%$ & $100.0 \%$ & $100.0 \%$ & $100.0 \%$ & $100.0 \%$ \\
\hline
\end{tabular}

Being a cross-border worker confers an obvious financial advantage in comparison with non-cross-border workers, especially in France. Indeed, $62.9 \%$ of cross-border workers are in a financially sound situation, compared to around $60 \%$ of the rest of the population who declare having little or no money left at the end of the month. In Germany, the households' situation appears to be better. Moreover, households without cross-border

to correct the share of cross-border workers. The sample is weighted by the size of the population, gender and age. 
workers are generally in much more difficult financial situations than households where at least one member (or two) works in Switzerland. The fact that only one member of the household is a cross-border worker is enough to significantly increase the household's income. These results show that many French households without a Swiss income are in difficult financial situations. The high cost of living in Southern Alsace was mentioned by several respondents and may explain this situation.

Longer working times and a weaker job stability are frequently put forward by cross-border workers in order to 'justify' their higher income. Indeed, they are proportionally more likely (around 80\%, both in France and Germany) than non-cross-border workers to work over 40 hours per week. It should be mentioned that the legal working time is shorter in France (35h) and Germany (40h) than in Switzerland (usually 41-42h). Thus, being a cross-border worker implies, whether or not by choice, a longer working time.

\section{Table 3}

Working time, differences between cross-border workers and non-cross-border workers

\begin{tabular}{lrr|rr}
\hline & \multicolumn{2}{c|}{ German } & \multicolumn{2}{c}{ French } \\
\cline { 2 - 5 } & $\begin{array}{c}\text { Cross-border } \\
\text { workers }\end{array}$ & $\begin{array}{c}\text { Non-cross- } \\
\text { border } \\
\text { workers }\end{array}$ & $\begin{array}{c}\text { Cross-border } \\
\text { workers }\end{array}$ & $\begin{array}{c}\text { Non-cross- } \\
\text { border } \\
\text { workers }\end{array}$ \\
\hline Less than 30 hours of work per week & $11.4 \%$ & $31.0 \%$ & $8.0 \%$ & $15.6 \%$ \\
30 to 40 hours of work per week & $5.7 \%$ & $21.7 \%$ & $13.1 \%$ & $51.6 \%$ \\
More than 40 hours of work per week & $82.9 \%$ & $47.3 \%$ & $79.0 \%$ & $32.8 \%$ \\
\hline Total & $100.0 \%$ & $100.0 \%$ & $100.0 \%$ & $100.0 \%$ \\
\hline
\end{tabular}

Despite longer working hours and longer commuting times, crossborder workers do not declare themselves less satisfied than non-crossborder workers with the time they have at their disposal for family life and leisure. Whereas longer working times may be a downside of working conditions in Switzerland, cross-border workers are more likely to have flexibility in their working hours: among Germans, only a quarter do not have any kind of flexibility versus one third of non-cross-border workers. Among the French, more than half of the non-cross-border workers do not have this possibility compared to $31.3 \%$ of cross-border workers. This shows significant differences, especially between the French job market 
and practices in Switzerland and Germany. Being able to choose, within certain limits, when one starts and ends one's working day offers a definite advantage, especially when it comes to commuting.

\section{Table 4}

Satisfaction of job, financial situation and time at disposal and job stability, differences between cross-border workers and non-cross-border workers

\begin{tabular}{|c|c|c|c|c|c|c|}
\hline & \multicolumn{3}{|c|}{ German } & \multicolumn{3}{|c|}{ French } \\
\hline & $\begin{array}{l}\text { Cross- } \\
\text { border } \\
\text { workers }\end{array}$ & $\begin{array}{l}\text { Non-cross- } \\
\text { border } \\
\text { workers }\end{array}$ & $\begin{array}{c}\text { Non- } \\
\text { workers }\end{array}$ & $\begin{array}{l}\text { Cross- } \\
\text { border } \\
\text { workers }\end{array}$ & $\begin{array}{l}\text { Non-cross- } \\
\text { border } \\
\text { workers }\end{array}$ & $\begin{array}{c}\text { Non- } \\
\text { workers }\end{array}$ \\
\hline $\begin{array}{l}\text { Job stability degree (stand- } \\
\text { ardized scale) }\end{array}$ & 0.71 & 0.8 & & 0.68 & 0.74 & \\
\hline $\begin{array}{c}\text { Job satisfaction degree } \\
\text { (standardized scale) }\end{array}$ & 0.75 & 0.79 & & 0.77 & 0.67 & \\
\hline $\begin{array}{l}\text { Financial situation satis- } \\
\text { faction degree (stand- } \\
\text { ardized scale) }\end{array}$ & 0.74 & 0.67 & 0.71 & 0.75 & 0.53 & 0.65 \\
\hline $\begin{array}{l}\text { Time at disposal for leisure } \\
\text { and private life satis- } \\
\text { faction (standardized } \\
\text { scale) }\end{array}$ & 0.60 & 0.61 & 0.84 & 0.57 & 0.57 & 0.78 \\
\hline
\end{tabular}

Regarding the stability of their job, cross-border workers tend to be more sceptical. Indeed, they feel less protected than if they were on the French or German job markets. Legislation on dismissal or redundancy is known to be far more liberal in Switzerland. People working in France also appear to be worried by the stability of their job, more than those working in Germany. This may be a consequence of the climate of economic insecurity which has been pervasive for many years in France. This feeling of job instability seems to be contingent to the specificity of the crossborder worker status, since the Swiss (working in the Swiss job market) feel safer about their jobs, at a similar level to the Germans working in their own country. Beyond economic aspects that may influence job stability, the survey was conducted after the vote on mass immigration (mentioned in the introduction), which caused uneasiness among cross-border workers, contributing without doubt to this climate of uncertainty. Likewise, having a professional activity abroad creates spaces of uncertainty linked with 
the tax system, social insurance (unemployment and retirement funds) or healthcare issues, for example in France the health insurance reform ${ }^{35}$.

Concerning job satisfaction, differences between cross-border workers and non-cross-border workers are non-significant in Germany, although the latter seem to appreciate their job slightly better. In France, on the contrary, cross-border workers are much more satisfied. A look at the financial satisfaction confirms these results. Cross-border workers are much more satisfied than non-cross-border workers (especially) and non-workers by the amount of money they have to live with: differences are particularly high in France where non-cross-border workers are not satisfied with their financial situation, in comparison with German non-cross-border workers. The German job market appears clearly more attractive than the French one, and seems to a certain extent able to keep German workers on the local (national) job market. This explains, partly, the smaller penetration of cross-border work in this country. In France, the situation on the job market and the working conditions (wages, flexibility, etc.) are far less competitive, resulting in numerous flows towards Switzerland. The French part finds itself in a situation of strong economic dependency towards Switzerland.

At a more individual level, earning more money seems to compensate to a large extent the negative aspects of cross-border work, in terms of having less time at one's disposal or a lower job stability. Cross-border workers are in much better situations, financially speaking, than the rest of the population, which leads to inequality between those who have access to Swiss pay slips and those who need to survive on a French, or to a lesser extent German, income. In France especially, these great differences could damage social cohesion between inhabitants of southern Alsace, as long as there is no sufficient regulation mechanisms to correct them. In other cross-border contexts, such as the French part of the Geneva area or the Italian side of the Ticino region, such inequalities exist as well and may even be stronger.

\section{Spatiality of Daily Life}

Living conditions are very different between cross-border workers and the rest of the population. Their respective financial capacities have impacts on the spatiality of their daily life and their practices at the cross-border scale.

The analysis of the daily food consumption in Switzerland by crossborder workers and non-cross-border workers gives a first insight into the

35 Auburtin,»Anciennes frontières, nouvelles discontinuités: les impacts du développement du travail frontalier sur les populations et les territoires du Nord lorrain» 
unique configurations of daily life in the trinational area. Around $8 \%$ of German cross-border workers declare buying food in Switzerland at least once a week and $27.5 \%$ at least once a month. French cross-border workers buy food products more frequently in Switzerland: one quarter at least once a week and another third at least once a month. If we look at the practices of the rest of the inhabitants, in Germany, non-cross-border workers almost never go to Switzerland for this kind of product, unlike non-workers, who go to Swiss shops almost more often than cross-border workers. These tendencies are somewhat different in France. Non-cross-border workers seldom go to Switzerland to buy food, or only from time to time (16\% at least once a month). On the contrary, non-workers go there quite frequently. Insights from the qualitative part show that their food consumption in Switzerland concerns mostly the purchase of errands, food for lunches, specific products that are cheaper or qualitatively better in Switzerland, or Swiss culinary specialties that are difficult to find elsewhere, whereas the bulk of the shopping is done elsewhere.
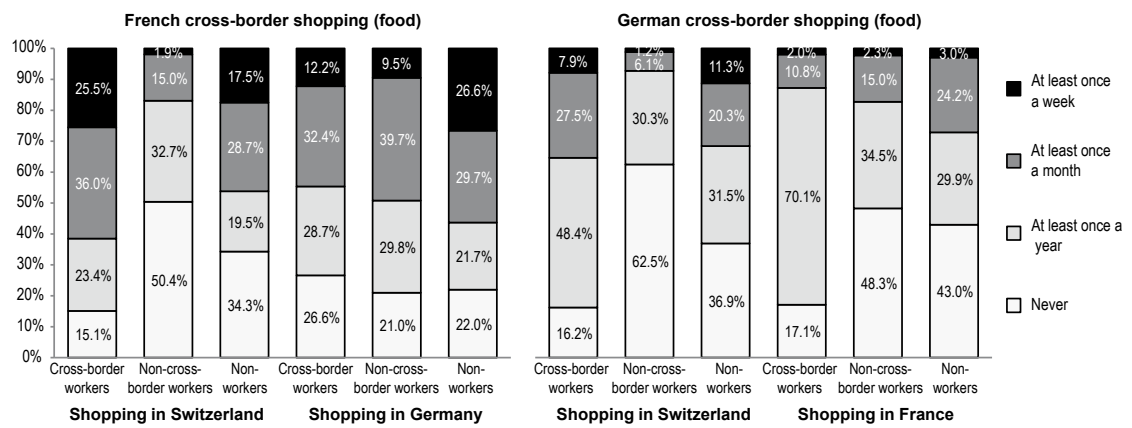

\section{Figure 1}

Cross-border shopping:

Differences between cross-border workers and non-cross-border workers

For the French, Germany represents a favoured destination for the purchase of everyday goods in large quantities. As shown in the figure above, the French, and more specifically the non-cross-border workers, often go to Germany for shopping purposes. Actually, it is one of the key points in the cross-border relationships in this region. Too high prices in southern Alsace, on the housing market for example, complicate the life of people who earn (only) French pays, as we have seen beforehand. Nevertheless, the possibility of buying a whole range of more affordable 
products (food, personal care, furniture) allows non-cross-border workers to compensate for the high cost of living in their home region. Germany is used as an 'escape valve'. Even more than non-cross-border workers, it is people with low incomes who go the most frequently to Germany: almost $60 \%$ of them purchase food there at least once a month. Some of the French, with limited financial resources, buy almost all of their products in Germany: shopping in France would be too expensive for them. Although cross-border workers also take the opportunity of buying cheaper products in Germany, $45 \%$ of them do it regularly despite their higher purchasing power. Beyond the financial appeal, it is easier for some motorized crossborderworkers to drive through Germany to go back home: they take advantage of this to stop and shop. For Germans, the reality is different as they do not have this 'escape' valve; however the pressure is weaker, because of the smaller gap between local and Swiss wages and the smaller share of cross-borderworkers. This situation could change and become more difficult to handle if the number of cross-border workers were to increase massively in the German part of the urban area.

Concerning leisure practiced at the cross-border scale, on the one hand, economic aspects appear to be less central and the logic at work is more complex (linguistic differences, mentality differences, secondary socialization of the cross-border workers, etc.). On the other hand, leisure cross-border mobility is largely directed towards Switzerland, where the supply is far more important than in the neighbouring territories, especially regarding 'urban leisure' (culture, bars/restaurants, urban strolling). The French, generally speaking, go more frequently than the Germans into Switzerland for reasons related to leisure or culture. Moreover, the French also cross into Germany, thus, they are proportionally more likely to take advantage of the cross-border opportunities. On the contrary, the Germans, while they use the Swiss leisure supply, almost never cross the Rhine towards France and this affects their general practice of the cross-border metropolis. Although the French go foremost to Switzerland during their free time (whether they are cross-border workers or not), non-cross-border workers give priority to Germany, whether for restaurants and bars or for shopping. Indeed, German restaurants are known to be cheap and good. Going to Germany allows non-cross-border workers (and people with low incomes) to eat out of home more frequently than if they stayed in France, and in doing so, to add some diversity to their leisure patterns.

Lifestyles in the region integrate a strong cross-border dimension, especially for cross-borderworkers and the French. Among the latter, important financial constraints bring them to consume in Germany. On the contrary, the Germans are less active at the cross-border level. 


\section{Special Issues Related to the Border}

In cross-border regions, the relatively new opening of borders and especially the fast and important development of cross-border relations have largely contributed to the modification of local territorial configurations. This evolution is not always welcomed by the population: the introduction showed that the situation is quite tense in many Swiss cross-border areas, where problems and tensions are to be observed at an economic, social or mobility-related level. On the contrary, in the trinational metropolis of Basel the situation appears mostly favourable and calm: three quarters of the inhabitants (including the Swiss) feel attached to it and 80\% declare that living in a region with open borders is an advantage. Indeed, cross-border relationships go far beyond 'simple utilitarian' commuting. This is supported by strong cross-border cooperation and the promotion of a common vision of the trinational metropolis. In addition, it must be noted, that the demographic pressure on the French and German territories and increase of cross-border workers is lower, than in Geneva or in the Ticino regions. This has allowed public authorities to better accompany these dynamics, in terms of urban and transport planning. While the system of the metropolis has functioned until now, it nevertheless presents some weaknesses. Actually, the spatial or the political configuration of the metropolis contributes to the fact that the negative aspects have not (yet) turned into serious tensions. Two major risks or challenges can be emphasized through the daily life of the region's inhabitants, namely: living conditions and the mobility issue.

\section{Tough Living Conditions for Non-Cross-border Workers}

In the first part of the results, we underlined the fact that the living conditions, especially in connection with the financial aspects, were clearly different between cross-border workers, who have a larger income, and the rest of the local population. In a region where life is expensive, these gaps contribute to a strongly unequal situation between cross-border workers and non-crossborder workers. Some are thus obliged to shop in Germany to make use of cheaper prices. This possibility makes the situation more bearable for noncross-border workers, although it excludes people who cannot or will not go to Germany. On the one hand, there is no public transport between Germany and France in the region; on the other hand, some French people (as also the Germans or Swiss) prefer for ethical reasons to buy products coming from their own country, to buy in French shops, in order to support the national economy ${ }^{36}$.

${ }^{36}$ Francis Piron,'International outshopping and ethnocentrism", European Journal of Marketing 36 1/2 (2002): 189-210. 
In France, the gap between these attitudes and effective cross-border shopping practices is stronger, probably indicating, that despite the desire to buy in France, it is impossible for many of them to do it.

In spite of these important constraints and the tight financial situations experienced by some households, the majority of individuals find some benefit in this 'special' trinational configuration. However, a part of the population, especially among non-cross-border workers (33\% in France and $29 \%$ in Germany) feel weakly or not at all attached to the trinational metropolis. Financial issues and the working conditions of non-cross-border workers seem to contribute to this result, especially in the French part. The 'privileged' lifestyle of cross-border workers is somehow envied, especially in its most visible features: their 'big' cars or 'big' houses are criticized while the non-cross-border workers suffer from the high cost of living, especially in connection with the housing market.

Using a linear model, it appears that in France among non-crossborder workers, those with a low income are less attached to the trinational metropolis. Beyond the financial issue, it is also a matter of jealousy towards cross-border workers or frustration regarding their working conditions (including financial aspects). Thus, people with a high level of education have a higher probability to be less attached to the trinational metropolis, as well as those who do not speak German or have only poor knowledge of it. This lack of linguistic skills can impede access to jobs on the other side of the border and can result in frustration. Actually, many surveyed people declare that the majority of the inhabitants of the French part would be, in the absolute, tempted by working in Switzerland. In general, non-crossborder workers who are not satisfied with their job are more likely not to be attached to the metropolis. In Germany, the model shows that both the richest and the poorest are less attached to the metropolis. This suggests that, although the economic condition has an effect like in France, other

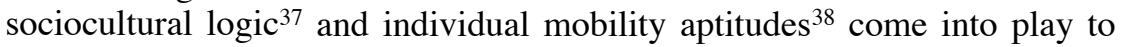
explain attachment to the metropolitan area of Basel.

Lack of financial resources restrains the participation in the life of the metropolis. Many regret that they cannot afford to do activities in

37 In the German-speaking part of Switzerland, the "large" presence of Germans living there is sometimes criticized. This feeling against Germans may contribute to this weaker attachment to the trinational metropolis. Indeed, we do not observe any differences of attachment between cross-border and non-cross-border workers among Germans.

38 Yann Dubois and Vincent Kaufmann, «Les échelles de la vie quotidienne dans l'agglomération transfrontalière de Bâle : une analyse à travers le potentiel de mobilité», in Frontières et représentations sociales : questions et perspectives méthodologiques, S. Considère and T. Perrin (eds.): (Louvain-la-Neuve: Harmattan-Academia, 2017). 
Switzerland because of the high prices of goods and leisure activities. The strong Swiss Franc has led people with low incomes and non-cross-border workers to decrease their cross-border activities in Switzerland during the last five years, or at least has impeded their development.

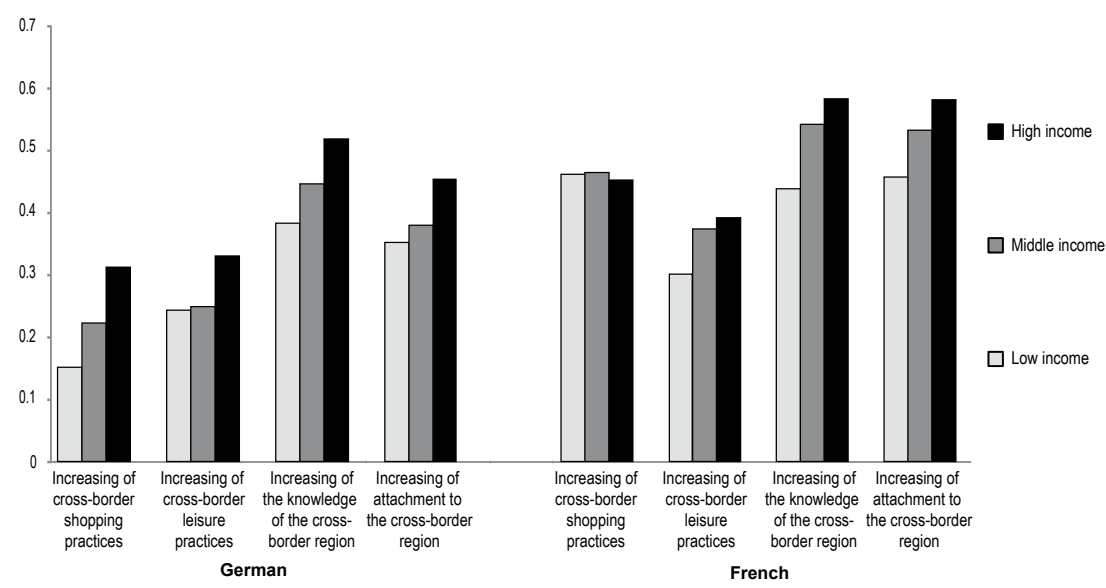

Figure 2

Evolution of cross-border relationships during the five last year

Money plays a big part in the evolution of cross-border relationships (spatial practices, local knowledge or spatial attachment) through time. The richer people are, the more likely they are to have increased their participation in the trinational metropolis. For the less wealthy, this means higher odds of stagnating or even decreasing cross-border relationships. Even though the fact of being a cross-border worker explains to a certain extent this evolution, because they have higher income or because they practice the Swiss Territory on a daily basis, income per se still has an impact. Non-cross-border workers seem in a way excluded from participation in the trinational metropolis, or in any case the economic accessibility to Switzerland has become restricted to those earning Swiss (or large) salaries. One exception to these trends is the transfer of the French shopping practices from Switzerland to Germany (especially among low income households): namely shopping in Germany to make the most of its cheap products. For German non-cross-border workers these evolutions mean a growing withdrawal from cross-border life. 


\section{Mobility}

The second challenge that the trinational metropolis of Basel faces is linked to daily mobility practices. One of the major stumbling blocks in the region, principally a criticism expressed by Swiss inhabitants, is the frequent car use by cross-border workers. In all of the interviews, the question of congestion in Basel was raised, as well as the lack of parking spaces. Among the Swiss, but not only, many mentioned the (too) numerous cars from Germany and France, their dangerous driving through residential areas or the lack of consideration of cyclists. These facts contribute to tense relations, even if the tension seems not to have reached the same level as in Geneva, Ticino or in the Swiss-French Jura region, to mention only Swiss examples. This arises partly from very different mobility expectations and mobility practices among cross-border workers, or more broadly inhabitants of the French and German parts, and the Swiss, which complicates the cohabitation of all inhabitants in the region. Basel residents and those living in the inner (Swiss) suburbs have particularly sustainable mobility behaviours; among other things, it is actually the Swiss city where bicycles are the most used. The frequent car use by cross-borderworkers leads to a 'clash' of mobility cultures $^{39}$. Figures below represent the frequency of car and public transport use in the different parts of the metropolis. It appears that people use more public transport and less cars in Swiss periurban areas than in the cities of Saint-Louis and Weil am Rhein, thus illustrating totally different lifestyles.

Quantitatively, cross-border workers trips account for many tens of thousands of cars crossing the border every working day. In Basel, it has been estimated that $82 \%$ of all trips from the two neighbouring countries are made by car ( $80 \%$ from Germany and $85.4 \%$ from France). Moreover, car trips are a highly visible display of cross-border work, easily recognizable because of the foreign licence plates, and recurring in the same places at the same times every day. The other controversial aspects of cross-border work, such as pressure on wages or on jobs, if they exist, are much less visible and affect less directly the majority of individuals. On the contrary, individual motorized traffic directly affects the quality of life of Swiss inhabitants, even more when traffic spills out of the main thoroughfares. According to interviewees, French drivers are less 'bicycle-friendly' than those from Switzerland or Germany. Interestingly, the French interviewed in this study described the bicycle as more dangerous than their Swiss or German neighbours. The more frequent use of the bicycle in the two latter countries probably has a positive effect on the drivers' respect towards cyclists. The

${ }^{39}$ Ole B. Jensen,"'Facework', Flow and the City: Simmel, Goffman, and Mobility in the Contemporary City", Mobilities 12 (2006): 143-165. 
overflow of cross-border workers' cars from main roads towards residential streets is also a source of tension. Many examples from the qualitative survey have shown that cross-border workers are not necessarily aware that their mobility behaviour, such as taking a shortcut through residential areas to save a few minutes, generates tension among local residents. Thus, the nuisance caused by commuters driving to Basel, whether they are Swiss or cross-borderworkers, is difficult to endure by the urban population. Beyond that, the lack of reflexivity about one's practices in matter of mobility and its impacts on territories and people is deplored.
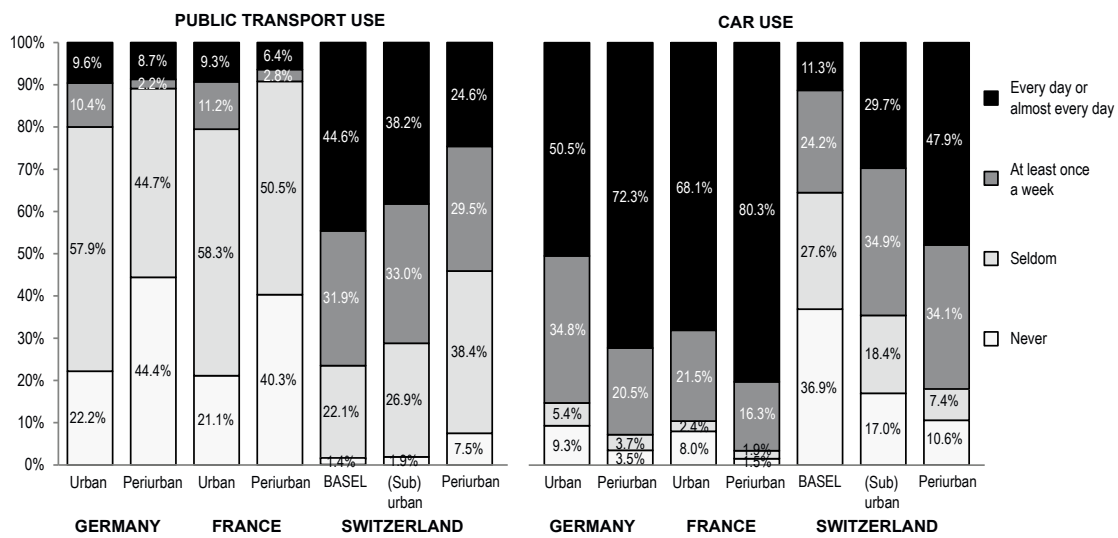

Figure 3

Public transport and car use in the trinational metropolis of Basel

It should be noted that cross-border worker mobility is even worse elsewhere, and does indeed contribute to very tense situations. In Geneva, $92 \%$ of trips from nearby regions in France are made by car ${ }^{40}$ and crossborder car traffic is a recurring political issue, especially visible in the attacks on cross-border workers by a populist political party [Mouvement Citoyens Genevois] with slogans such as "Give Genevans their streets back! Stop CROSS-BORDER WORKERS cars at customs" 41 . In the Canton of Neuchatel, $95 \%$ of cross-border workers commute by car, a situation that also

40 CITEC, Enquête sur les flux de déplacements à la frontière: résultats 2011, Rapport technique, GLCT Transports publics Grand Genève, 2012.

${ }^{41}$ Own translation, french original : "Rendons les rues aux Genevois! Bloquons les voitures des FRONTALIERS aux douanes. 
leads to considerable tensions ${ }^{42}$. In Basel, efforts made over several years in setting up cross-border transport infrastructure (S-Bahn, trams and bus lines, park-and-ride amenities, promotion of walking and cycling, parking restrictions) highly contribute to a less tense situation, despite criticisms heard during the interviews. Cross-border worker mobility behaviours show that they use more public transport and less cars than their fellow citizens.

Whereas the cross-border public transport supply is well-developed, as the one around workplaces, the supply located around the places of residence, in the French and German areas, does not meet the needs of cross-border workers. Accessibility to the cross-border transport lines is hardly achievable by public transport. Thus some prefer to park next to the border and cross it on foot in order to access the Swiss transport network. These interesting patterns in the cross-border workers' commuting trips imply that modal practices are almost entirely determined by the territory: public transport is always used in the Swiss part and never in the French or German parts.

Trips using public transportation inside Germany or France seem to represent the major problem regarding modal shift in the region, as well as trips done outside peak hours across borders, while cross-border workers like to stay in Switzerland after work to undertake diverse activities. Moreover, whereas parking difficulties in Basel were mentioned many times, a survey ${ }^{43}$ underlines that almost $80 \%$ of cross-border workers using cars have access to sufficient parking lots on their workplace, decreasing de facto the incentives to use other modes than the car...

\section{Conclusions}

The opening of borders has led to considerable mobility flows across borders in some regions of Europe, through classical immigration or crossborder work. These mobilities have large economic, environmental or social impacts on local territories, which were not prepared for such an influx. These flows cause tensions in the local population and to a certain extent strengthen expectations towards more international or cross-border mobility regulation. These tendencies are part of a wider period of doubts on the globalization model and a certain reluctance towards free movement of people in different European countries or even at the world scale.

${ }^{42}$ RTS, Le Locle, la libre circulation bouchonne - Quinze Minutes (Émission radiophonique), 1 février $2014 \mathrm{http} / / \mathrm{ww} w . r t s . c h / l a-1 \mathrm{ere} /$ programmes/quinze-minutes/ 5557727-le-locle-la-libre-circulation-bouchonne-01-02-2014.html, consulted on 26 June 2016.

${ }^{43}$ PTV, Enquête Cordon aux frontières de l'Eurodistrict Trinational de Bâle, ETB 2012. 
Analyses made in this article have shown that cross-border work has a great effect on lifestyles in the region, in economic terms, but also in terms of daily practices. Although cross-border workers use the territory of the trinational metropolis more than others, non-cross-border workers also do cross the borders for shopping or leisure activities. A key point of the analysis is the prevailing relative harmony in the metropolitan area of Basel, compared to more tense situations in Geneva or Ticino.

However, the functioning of the metropolis also shows weaknesses; many elements that are also to be found in other cross-border cities can represent large risks. The first risk is connected to the inequality created by the strong income differences between cross-border workers and the rest of the population, especially in France. The possibility of buying goods in Germany where the prices are lower, a local specificity that is not found elsewhere, makes the situation more bearable. Nevertheless, the sustainability of such a model can be questioned and more specifically its dependency towards the neighbouring countries. The second risk concerns cross-border mobility, and especially car use by cross-border workers. Indeed, in Swiss cross-border cities, it causes trouble in the relationships between the Swiss and their neighbours. Motorized cross-border traffic is particularly obvious and directly affects quality of life: it therefore plays a big role in the tensions on cross-border work. It may be possible that fears aroused by cross-border work on jobs and wages in Switzerland are transferred towards car use: it is socially more acceptable to be against cross-border cars than against cross-border workers themselves... By investing massively in cross-border public transport infrastructure, the public authorities of the Basel area have been able to avoid, to a certain extent and at least until now, too much bad feeling on that matter.

Another major challenge that cross-border cities are confronted with are the impacts of cross-border work on employment (in Switzerland): our data were not suited to address this concern. Although it is difficult to evaluate these impacts from a scientific point of view, they participate in creating a climate of uncertainty and fear in the population. Generally speaking, a better knowledge and a better consideration of the experience and feelings of the inhabitants as well as the specificities of cross-border territories in national or international policies are essential in order to find lasting solutions.

The situation of the trinational metropolis of Basel, put into perspective with other examples, shows the needs of setting up multi-scale solutions in order to accompany the development of cross-border regions. To some extent, it means a "regulation" of cross-border flows, not in order to stop them, but in order to maintain the possibility of cross-border work-related mobility, while making it more "sustainable" socially, economically 
and environmentally. At different scales (local, cross-border, national or even European), the opportunity of setting up regulatory or redistribution mechanisms must be discussed, to tackle potential negative impacts of these flows on the population, especially on non-cross-border workers. More generally, it seems essential to better consider, through concrete policies, those who are the most affected and those who benefit directly the less from an open border situation. In addition, solutions in terms of governance at the cross-border urban scale have to be found. In this respect, the trinational metropolis of Basel is an example: numerous projects done on this scale are materialized into concrete implementations, in terms of planning and transport. The regulation of cross-border daily mobility flows is crucial, as motorized traffic is one of the major issues that this region and also other cross-border regions face.

Finally, inhabitants of these regions and the private sector also have a role to play. In this respect, tensions resulting from daily practices are mainly caused by ignorance or a weak consideration of the different interests and expectations that people can have, depending on the side of the border where they find themselves. In fostering a better consideration of the impacts and the links that everyone's practices or decisions have on other individuals or territories ${ }^{44},{ }^{45}$-at individual, company or public authority scale, in Switzerland, France or Germany - the good functioning of the trinational of Basel could be preserved. More generally, coherent policies in order to lessen the negative impacts of cross-border mobility may prevent the implementation of highly restrictive measures at the national level, particularly harmful for the development of cross-border territories as well as for the "European project".

\section{Bibliography}

Alm, Leslie R. and Ross E. Burkhart. « Bridges and Barriers: The Lake Superior Borderlands ». Journal of Borderlands Studies 28, 1 (2013): 47-60.

Auburtin, Éric. « Anciennes frontières, nouvelles discontinuités: les impacts du développement du travail frontalier sur les populations et les territoires du Nord lorrain ». Espace populations sociétés 2005, 2 (2005): 199-210.

Balibar, Etienne. «The Borders of Europe ». In Cosmopolitics: Thinking and Feeling Beyond the Nation. ed. Pheng Cheah and Bruce Robbins, 216-229. Minneapolis: University of Minnesota Press, 1998.

44 Doreen Massey,"Geographies of Responsibility", Geografiska Annaler: Series B, Human Geography 861 (2004): 5-18.

45 Iris Marion Young,»Responsibility and Global Justice: A Social Connection Model», Anales de la Cátedra Francisco Suárez 39 (2005): 709-726. 
Baruffini, Moreno, Valentina Mini, Rico Maggi and George Sheldon. Approfondimento della situazione del mercato del lavoro ticinese negli anni successivi all'introduzione dell 'Accordo sulla Libera Circolazione delle Persone (ALCP) - Rapporto di ricerca. Lugano: IRE-Università della Svizzera italiana, 2015.

Belkacem, Rachid, Monique Borsenberger and Isabelle Pigeron-Piroth. « Les travailleurs frontaliers lorrains ». Travail et emploi 105, (2006): 65-77.

Beyer, Antoine. «L'enjeu transfrontalier de l'extension des réseaux de tramway urbain à Strasbourg et à Bâle ». In Le tramway dans la ville. Le projet urbain négocié à l'aune des déplacements, ed. Philipe Hamman, 253-267. Rennes: Presses universitaires de Rennes, 2011.

Blake, Gerald. «State limits in the early twenty-first century: Observations on form and function». Geopolitics 5, 1 (2000): 1-18.

Bolzman, Claudio and Marie Vial. Migrants au quotidien : les frontaliers. Pratiques, représentations et identités collectives. Zurich: Seismo, 2007.

Costa, Rafael and Thierry Eggerickx. «Diversité démographique et profils migratoires des espaces frontaliers belges ». Géo-Regards 4, (2011): 113-134.

Crevoisier, Olivier and Alexande Moine. Impact de l'accord bilatéral relatif à la libre circulation des personnes sur la région transfrontalière du canton de Neuchâtel et du département du Doubs. Neuchâtel - Besançon: GRET-THEMA, 2006.

Dubois, Yann and Vincent Kaufmann. «Les échelles de la vie quotidienne dans l'agglomération transfrontalière de Bâle : une analyse à travers le potentiel de mobilité ». In Frontières et représentations sociales : questions et perspectives méthodologiques, ed. Sylvie Considère and Thomas Perrin, Louvain-la-Neuve: Harmattan-Academia, 2017.

Flückiger, Yves and Yves Perrin. Pas de lien direct entre chômage et maind'oeuvre frontalière. Genève, 2005.

Foucher, Michel. L'obsession des frontières. Paris: Perrin, 2007.

Gerber, Philippe. «Advancement in Conceptualizing Cross-Border Daily Mobility: the Benelux Context in the European Union ». EJTIR 12, 2 (2012): 178-197.

Jensen, Ole B. «'Facework', Flow and the City: Simmel, Goffman, and Mobility in the Contemporary City ». Mobilities 1, 2 (2006): 143-165.

Kempeneers, Pierre and Yves Flückiger. Immigration, libre circulation des personnes et marché de l'emploi. Genève: Observatoire Universitaire de l'Emploi, 2012.

Massey, Doreen. « Geographies of Responsibility ». Geografiska Annaler: Series B, Human Geography 86, 1 (2004): 5-18.

MKW and Empirica. Scientific Report on the Mobility of Cross-Border Workers within the EU-27/EEA/EFTA Countries. Munich, Sopron: European Commission DG Employment and Social Affairs, 2009.

Newman, David. « The lines that continue to separate us: borders in our 'borderless' world ». Progress in Human Geography 30, 2 (2006): 143-161.

O'Dowd, Liam. «The Changing Significance of European Borders ». Regional \& Federal Studies 12, 4 (2002): 13-36.

Ohmae, Kenichi. The borderless world. Power and strategy in the interlinked economy. London: Collins, 1990. 
Pellizzari, Michele, Giovanni Ferro Luzzi and Sabina Neacsu. La contribution des actifs transfrontaliers à l'économie de l'Espace lémanique. Rapport à l'intention du Conseil du Léman. Université de Genève: Laboratoire d'économie appliquée, 2016.

Piron, Francis. «International outshopping and ethnocentrism ». European Journal of Marketing 36, 1/2 (2002): 189-210.

Rietveld, Piet. «Barrier Effects of Borders: Implications for Border-Crossing Infrastructures ». EJTIR 12, 2 (2012): 150-166.

Sohn, Christophe. «The Border as a Resource in the Global Urban Space: A Contribution to the Cross-Border Metropolis Hypothesis ». International Journal of Urban and Regional Research 38, 5 (2013): 1697-1711.

Sohn, Christophe, Bernard Reitel and Olivier Walther. « Cross-border metropolitan integration in Europe: the case of Luxembourg, Basel, and Geneva ». Environment and Planning C: Government and Policy 27, (2009): 922-939.

Soutif, Véronique. L'intégration européenne et les travailleurs frontaliers de l'Europe occidentale. Angers, 1997.

Strüver, Anke. «'Everyone Creates One's Own Borders': The Dutch-German Borderland as Representation ». Geopolitics 9, 3 (2004): 627-648.

Thomas, Marie-Paule, Hossam Adly, Luca Pattaroni, Vincent Kaufmann and Simon Galloux. Choix résidentiels et modes de vie dans l'agglomération franco-valdogenevoise. Grand Genève, 2011.

Van Geenhuizen, Marina and Remigio Ratti. Gaining Advantages from Open Borders. An active space approach to regional development. Aldershot: Ashgate, 2001.

van Houtum, Henk. "The Mask of the Border ». En The Ashgate Research Companion to Border Studies, ed. Wastl-Walter D., 46-61, Farnahm: Ashgate, 2011.

van Houtum, Henk and Martin van der Velde. « The power of cross-border labour and market immobility ». Tijdschrift voor Economische en Sociale Geografi 95 , 1 (2004): 100-107.

Vigani, Aurelio. «Transports, frontière et développement territorial de la Regio Insubrica ». Géo-Regards 4, (2011): 95-11.

Wastl-Walter, Doris. «Borderlands ». In International Encyclopedia of Human Geography, ed. Kitchin R. and Thrift N., 332-339. Oxford: Elsevier, 2009.

Young, Iris Marion. « Responsibility and Global Justice: A Social Connection Model ». Anales de la Cátedra Francisco Suárez 39, (2005): 709-726. 


\section{Derechos de autor}

Los derechos de autor (para la distribución, comunicación pública, reproducción e inclusión en bases de datos de indexación y repositorios institucionales) de esta publicación (Cuadernos Europeos de Deusto, CED) pertenecen a la editorial Universidad de Deusto. El acceso al contenido digital de cualquier número de Cuadernos Europeos de Deusto es gratuito, transcurridos 6 meses desde su publicación. Los trabajos podrán descargarse, copiar y difundir en cualquier medio sin fines comerciales y según lo previsto por la ley; sin la previa autorización de la Editorial (Universidad de Deusto) o el autor. Así mismo, los trabajos editados en CED pueden ser publicados con posterioridad en otros medios o revistas, siempre que el autor indique con claridad y en la primera nota a pie de página que el trabajo se publicó por primera vez en $C E D$, con indicación del número, año, páginas y DOI (si procede). Cualquier otro uso de su contenido en cualquier medio o formato, ahora conocido o desarrollado en el futuro, requiere el permiso previo por escrito del titular de los derechos de autor.

\section{Copyright}

Copyright (for distribution, public communication, reproduction and inclusion in indexation databases and institutional repositories) of this publication (Cuadernos Europeos de Deusto, CED) belongs to the publisher University of Deusto. Access to the digital content of any Issue of Cuadernos Europeos de Deusto is free only six months after its publication. The content can be accessed, downloaded, copies, and distributed freely in any medium only for non-commercial purposes and in accordance with any applicable copyright legislation, without prior permission from the copyright holder (University of Deusto) or the author. Thus, the content of $C E D$ can be subsequently published in other media or journals, as long as the author clearly indicates in the first footnote that the work was published in $C E D$ for the first time, indicating the Issue number, year, pages, and DOI (if applicable). Any other use of its content in any medium or format, now known or developed in the future, requires prior written permission of the copyright holder. 